\title{
TTR
}

Traduction, terminologie, re?daction

\section{Understanding Why Translators Make Mistakes}

\section{Candace Séguinot}

Volume 2, numéro 2, 2e semestre 1989

L'erreur en traduction

URI : https://id.erudit.org/iderudit/037047ar

DOI : https://doi.org/10.7202/037047ar

Aller au sommaire du numéro

Éditeur(s)

Association canadienne de traductologie

ISSN

0835-8443 (imprimé)

1708-2188 (numérique)

Découvrir la revue

Citer cet article

Séguinot, C. (1989). Understanding Why Translators Make Mistakes. TTR, 2(2),

73-81. https://doi.org/10.7202/037047ar d'utilisation que vous pouvez consulter en ligne.

https://apropos.erudit.org/fr/usagers/politique-dutilisation/ 


\section{Understanding Why Translators Make Mistakes}

\section{Candace Séguinot}

\section{Introduction}

Every year an enormous amount of time and effort is spent on testing translation quality : testing job applicants and testing for the letting of contracts, examinations for accreditation in professional associations and entrance into educational institutions, job quality assessments and productivity reviews. All of these tests and exams have to be corrected, and correction means the identification and ranking of errors. It's amazing in a sense that more money is probably spent on signalling and classifying errors than on studying or eliminating them.

This signalling and classifying function explains the predominantly prescriptive approach to the study of errors in translation. A prescriptive approach defines error as a violation of translational or language norms. The focus of research done from this perspective is actually on explicitating the norms, deciding on the relative weighting of violations of norms, classifying violations into types, and suggesting correlations between numbers of errors and levels of competence. The nature of the error is not immanent, and it is subordinate to the applications made of the system of classification. For example, the interim edition of the Translation Bureau of the Secretary of State's Contractor's Guide Translation (1984, p. 10) distinguishes translation and language errors as follows:

- Translation refers to the accuracy of the rendering.

- Language denotes the expression in the target language : correctness, authenticity, appropriateness to the subject matter and purpose. 
The key terms in this definition are themselves defined (p. 2) in terms of norms :

... high quality transfer requires :

correctness, that is, observance of the rules of spelling, syntax and usage ;

authenticity, that is, a form of expression as natural as if the document had originally been written in the target language ;

appropriateness to subject and readership, that is, judicious use of the equivalents chosen during the period of reflection.

\section{Errors as Carriers of Meaning}

In a non-prescriptive study of errors the roles played by errors and norms are reversed: norms merely provide ways to identify errors, and errors are viewed as surface manifestations of phenomena which are the object of study. The search for the nature of translational operations is one of the objects-what could be termed a humanistie approach to the study of translation errors. The second kind of explanatory approach to the study of errors is the more concretely scientific : the possibility of making better predictions about what kind of errors are likely to occur in translation, where they are likely to occur, and under what conditions.

However, the use of errors as insights into the normal processes in translation is not exactly parallel to the study of an identifiable pathological condition, say aphasia, for evidence of neurological processes. There are different levels of competence in translation and different kinds of translation which give rise to different kinds of errors. And what is more, and the central issue in this paper, there are errors which are predictable if not inevitable due to the very nature of translation.

\section{Models as Metaphor}

The study of these kinds of predictable errors requires the kind of basic observational research that is just in its infancy (Harris, 1988, p. 94). Though certainly possible before, this kind of research has only been accepted as appropriate with the change in thinking about how communication operates, and hence a change in potentially acceptable models of communicative behaviour. In fields like psychology, linguistics, and translation, for most of this century the mind was thought of as a machine, a mechanism that could be described in terms of units and states. This model is implicit in much of the familiar work in translation that speaks of translation procedures and translation units, and until about fifteen years ago was the model for explaining the writing process. The last fifteen to twenty years has seen a shift in metaphor, so that in many disciplines the mind is described in terms 
of the make-up and functioning of a computer. This change in perspective has been labelled a process view, i.e. a focus on the process being actualized rather than an examination of a before-state and a result.

In translation the movement away from unit-centered models such as Jean-Paul Vinay and Jean Darbelnet's translation units or Hans Krings' translation problems has not been in the main to a process view, but to a receptor view. An analysis of the cultural and institutional influences on translation necessarily means working in a paradigm of mass communications. The prediction of errors, on the other hand, means looking at the behaviour of individuals and identifiable groups.

\section{Errors and the Individual}

\section{Limitations on Processing Capacity}

The primary explanation why even competent translators make mistakes is because human cognitive processing capacity is limited. Because we can only attend to so much with our conscious processes, we automatize as much as possible to leave our minds free for more difficult tasks. That means that our attention is directed to only some of the things we are doing at the same time.

A related constraint is the fact that there are limitations on short-term memory. The psychologist George Miller's famous article put it very nicely: "The magicical number seven, plus or minus two...". We can organize our intake so the seven or so items in fact contain items themselves, for example storing words as opposed to single letters, but there is nonetheless a limit after which memory fades. In an observational study I reported on elsewhere (Séguinot, 1989) there is some indication that professional translators may develop strategies to deal with these limitations on memory. The translator observed in that study made different kinds of error in the first part of sentences than towards the end of the sentences. The particular kinds of error indicate that the passage from the source text to the translation was probably through the memory of the content of the source text for the first part of the sentences, but clearly more from the surface of the source text as the translator's memory began to fade. When this happened, there were more examples of interference from the source text, more literal translation or transcoding.

A number of professional translators working in an institutional environment in a variety of languages have told me that they notice a rhythm to their translation. This rhythm may in fact be a sign of the differential strategies that experienced translators develop to maintain the translating impulse. This translating impulse is clear in other contexts as well. In a study of professional translators working from English to French that is currently in progress, I've noticed a number 
of false starts where the English has noun strings. The translator has read the sentence, seemed to decipher the meaning, but begun the translation before deciding on how to separate the information in the noun construction. Like the examples of the translator working with sentences too long to retain in short-term memory, these false starts indicate that experienced translators feel an impulse to continue translating as long as possible, leading to the possibility of errors.

\section{Parallel Processing and Forward Planning}

The translation process is not a step-by-step linear progression. When we translate, we are actually performing a number of tasks at the same time. We monitor our output and tend to correct mechanical errors as they occur. We do not search for words one at a time, wait until the search is successful, then search for a new word. The psycholinguistic research suggests that the unconscious operations involved in producing language can simultaneously pursue different options.

Our comprehension of text is also non-linear in that we are constantly making predictions about what is ahead. We do this on the basis of educated guesses. The education comes in several forms : experiences stored in the form of scripts, scenarios, frames, schema, i.e. patterns, which include knowledge about types of texts, language patterning, and content information about the way the world operates. There is also evidence in the video-taped observational studies that translators take less time making decisions about specific translation problems that recur as it becomes obvious that the same source language usage is being repeated with the same value. This leapfrogging is a potential source of error when the world of the source text does not unfold as expected. As Robert de Beaugrande (1984) has pointed out, a text may vary in complexity at different points, may differ in perceptual immediacy and informationality, may contain both familiar and unfamiliar elements. In translation there is also the goodness of fit of the words on the page and author's intent which is clear from other sources.

\section{Accessing Knowledge}

It used to be thought that lexical items were stored in the brain somewhat like in a dictionary. It appears as though this is not the case : information about items is not necessarily stored in the same way and does not all become available when part of the information available is accessed. For example, we have a level of tolerance for mispellings and misselection of words and we can access the intended meanings even when the surface forms are wrong. That means that there are separate access routes possible for the phonetic and orthogra- 
phic forms and the meaning of words. In reading, we can understand words by accessing them phonetically or globally.

The fact that there are different kinds of mapping available for the information clustered around any item and that there are different ways of activating that mapping explains another source of error. In a study referred to earlier I suggested that translators may use different strategies in different parts of a sentence to deal with constraints of short-term memory. One of the errors in the first part of the sentence seemed to show how the accessing of features of an item can lead to faulty associations in the selection of meaning. The translator was working with a sentence that began "Le principe". She typed "The principal ». She hesitated, then right away typed «main». This indicates that she was aware she had made a mistake, but did not realize that it was a mistake in spelling. She searched in the same semantic field as "principal" and came up with the synonym "main». When she revised her translation with the French in front of her, she crossed out both and misread the French text out loud to let me know why she was making the change, i.e. she made the French text she was reading from congruent with her translation, rather than catching her error from the source text.

We all have had the experience of being able to revise other people's work more easily than our own. The example of the translator who maps her own understanding of the source text over the actual text when she is reading is probably part of that same phenomenon, namely the inability to distance ourselves from our understanding of what we intended.

It is also clear that the very nature of meaning is indeterminate, that individuals share roughly similar but not necessarily identical networks of features for concepts. When René Lévesque was berating the other premiers to the press for having reached an agreement on the patriation of the Canadian constitution without him, he said that they were a bunch of "marchands de tapis". This was translated in the Anglophone media as "carpetbaggers " in one case, as "used car salesmen » in another. Both carry the negative connotations, but the referential inferences are completely different in the three cases.

\section{Motor Aspects of Production}

The pragmatics of the working situation may affect the output. The translation is produced in some form: dictated, typed, or written in longhand. These forms of production require effort from specific muscle groups and a certain amount of attention to specific termination stages such as the end of lines or tapes or screens. The indications are that certain forms of production may be more likely to induce certain kinds of error. 
Anyone who uses a word processor extensively for writing will discover the kind of error engendered specifically by working with a programme that allows for deletions and insertions and copying. Rereading an old text there is so little new information that it's hard to catch unwanted repetitions or mistaken deletions.

In the video-taped study referred to earlier, the professional translator working into English used a typewriter. There was clear evidence from the think-aloud protocol that she recognized certain deficiencies as she typed out the translation, but waited for a natural break to make changes. However, the amount of time the translator decides to keep changes in mind rather than making them immediately may eventually affect the number of errors.

There are other obvious factors that lead to a multiplication of errors: producing translations under severe time constraints, while performing other tasks that require undivided attention (like answering the phone), in the midst of external distractions or noise.

\section{Errors and Groups : Novices versus Experts}

Studies of skill development show that the differences between experts and novices is more than an accumulation of knowledge. The characteristics of levels of competence have been studied in a number of areas (reviewed in Dreyfus and Dreyfus, 1986) from the development of expertise in games to the acquisition of professional skills, and in language learning (Naiman, Frohlich, and Stern, 1975; Nation and McLaughlin, 1986) and composing skills (Bereiter, Burtis and Scardemalia, 1988). These studies show that the key feature of expertise in the performance of skills is the ability to restructure knowledge.

If competence is developed by processing, organizing, and accessing information in different ways, there may be certain kinds of errors that are associated with the passage from one level of competence to another. As a teacher of academic and technical writing, I've often noticed that many students actually seem to write worse as the fall term progresses; colleagues who teach similar courses have said that they've also noticed this phenomenon. One explanation may be that novices need to proceed step by step. They memorize rules, and tend to overgeneralize the domain of application of new material.

There is some support for this conclusion in the psychology studies that have been done of skill development. The example of the study of nurses cited in Dreyfus and Dreyfus showed that when inexperienced nurses went into a nursery to look after the babies, they went through the chart of information that provided the list of symptoms to check for with each baby, checking each item for each infant before going on to the next. The experienced nurses walked in and went immediately to the babies who seemed to be in distress and attended 
to whatever seemed to be wrong. The expert used intuition based on experience to match new situations to what he or she knew; the novice proceeded by the application of rules. At York, a colleague, Christine Klein-Lataud, and I are currently looking through data collected for a longitudinal study of students in translation. The preliminary results based on the testing done of the best students in translation show that they do in fact begin to make errors in the middle of their programme that they did not make at the beginning (Séguinot, forthcoming). The explanation I have suggested is that this increase in basic errors occurs when there are improvements in other areas, in particular as vocabulary becomes more complex and precise and as students pay more attention to style. Attending to specific aspects of translation may be a way of learning to improve, and the errors that result from this focussing of attention are not necessarily a reflection of overall competence.

\section{First and Second Language}

Just as there are errors which seem to come from the process of skill learning, there are errors which seem to come from the way second languages are stored and accessed. Leaving aside the obvious problems of lack of knowledge of the second language, there are errors which seem to be specifically translational in character. For example, both first and second language students tend to associate focus with words with the most semantic weight (Séguinot, 1988).

Second language students seem to make errors that can only be explained in terms of a recognition block. They seem to let individual words and phrases take prominence, so that they are unable to see the larger conceptual meaning on re-reading. My favourite example comes from a student in her third year of translation, a student who has since had a successful career as a professional translator. We were translating material for hospital insurance ; one of the choices the respondent had to make concerned the kind of room coverage. The French was :

une chambre à un lit une chambre à deux lits

The English should have been:

private room

semi-private room

What the student translated was:

single bed

double bed

This hasn't been an option in North America for quite some time. And the student of course knows this. This is not one of those cases where the student doesn't have the world knowledge or understanding of the technology. She simply doesn't see what she has written.

Why? Maybe because second language learners do not have as established connections between parts of collocations as native users of a language. We can access phrases in different ways : by looking 
for collocates, by looking for synonyms, by looking for referential terms, etc. It seems logical that in the semantic field of 'beds' the student may have been thinking ' $u n$, deux... un lit à deux places' which translates into 'double bed'. There's no way of knowing, of course, whether this was the case. However, this example shows a similar phenomenon to the example of the translator who misread the source text once she had finished her own translation. The student had model texts in which the correct English terms were used, had access to dictionaries in which she could have verified the terms. But she didn't, because it sounded right.

\section{Conclusion}

To conclude, there are errors which are associated with levels of competence, errors which arise because a translator does not understand the source language or manipulate the target language well enough, etc. But there are also errors that are a normal by-product of the translation process and errors that are normal in learning to translate. These errors can help us understand what happens when translation goes wrong, and through our understanding of these lapses, the nature of the translation processes themselves.

York University

\section{References}

BEAUGRANDE, Robert de (1984). Text Production: Toward a Science of Composition, Norwood (NJ), Ablex.

BEREITER, Carl, P.J. BURTIS, and Marlene SCARDEMALIA (1988). «Cognitive operations in constructing main points in a written composition». Journal of Memory and Language, vol. 27, pp. 261-278.

DREYFUS, H.L. and S.E. DREYFUS (1986). Mind over Machine, New York, The Free Press.

HARRIS, Brian (1988). « What I really meant by " Translatology » ". TTR (2), pp. 91-96.

KRINGS, Hans (1986). "Translation problems and translation strategies of advanced German learners of French (L2) ». Interlingual and Intercultural Communication, J. House and S. Blum-Kulka, eds., Tübingen, Gunter Narr, pp. 263-276.

MILLER, George (1956). "The magical number seven, plus or minus two: Some limits on our capacity for processing information ». Psychological Review, vol. 63, pp. 81-97. 
NAIMAN, Neil, Maria FROHLICH, and H.H. STERN (1975). The Good Language Learner, Toronto, The Ontario Institute for Studies in Education.

NATION, R. and B. McLAUGHLIN (1986). "Novices and experts: an information processing approach to the 'good language learner' ". $A p$ plied Psycholinguistics 7, pp. 41-55.

SÉGUINOT, Candace (1988). "A study of student translation strategies". Paper delivered at the Seminar on Empirical Research in Intercultural Studies and Translation, Savonlinna, Finland, 1988.

SÉGUINOT, Candace (1989). "The translation process: An experimental study". The Translation Process, C. Séguinot, ed., Toronto, H.G. Publications, The School of Translation, York University, pp. 21-54.

SÉGUINOT, Candace (forthcoming). « Interpreting errors in translation ", Actes du colloque sur 'La traduction proligère', Université de Montréal, 1989.

TRANSLATION BUREAU (1984). Contractor's Guide Translation, Ottawa, Department of the Secretary of State.

VINAY, Jean-Paul and Jean DARBELNET (1977). Stylistique comparée $d u$ français et de l'anglais, Montréal, Beauchemin. 